\title{
A Brief Analysis of Children's English Teaching based on Liberal Education
}

\author{
An Lu \\ School of Foreign Studies, Xi'an University, 710065 \\ Keywords: Liberal Education; Children's English; Teaching \\ Abstract: In recent years, with the popularity of English, children's English has become an \\ important part of the children's education system. Although there are many kinds of \\ children's English teaching in the market, there are few schools that can improve children's \\ English comprehensive ability and cultivate children's foreign cultural accomplishment. \\ Based on the current situation of Children's English teaching in China, this paper analyzes \\ the problems that should be paid attention to in liberal education children's English \\ teaching.
}

Language is a uniquely human ability.Let the child have the super language ability is every parent's common aspiration.People's language learning ability shows a gradual decline with the growth of age,therefore,children's language training stage for children is critical.It is for this reason that English training and teaching for young children has been springing up at present.Every child,only given a sufficient language environment,he can learn to master a certain language ability.Even deaf children,if properly trained,can plant the seeds of language in their brains and form a series of language system characteristics in the way they behave.The study of children's language potential is still at a relatively early stage,and we have no way to determine what the determinants of children's language ability are,but to judge from what we know so far,children have a special mechanism for language in their brains.

Humans are not born with language.Language is a broad concept,whenever a person speaks, his language contains complex components, both to involve changes in words,but also to involve sentence patterns and human factors. There are a lot of acquired factors in language cultivation,in other words,it has a great influence on the formation of language.

\section{The developmental track of children's language ability}

When a person enters the child's stage,his or her performance improves.The performance desire of children has been significantly improved compared to infants,their subconscious has been through the language to express their own needs.Children often express their inner feelings by shouting loudly when they encounter new things. Some children are also eager to let the adults know that they have mastered new knowledge,new words and so on.Children in their teens are always paying attention to the things around them. They will have repeated memory in their mind and carry out conscious practice.Children's ability to imitate is also gradually increasing.They to explore the world,learn new knowledge ,and master new skills through their own imitation.The children will 
often communicate with each other through their own way. It's a unique way for them to develop their language skills. It is precisely because children's attention to the novelty around, the external environment in the formation of their language ability plays a very important role. Peer Relationship, language atmosphere and even imitative objects can affect the formation and development of children's language ability.

Generally speaking, the formation of children's language ability is a process from inside to outside and then from outside to inside. The positive external factors will promote the internal motivation of children's language learning and play a key role in promoting the development of children's language ability. The research on the relationship between external environment and language formation started late in China. Children's language skills develop about one to two years later than those of the same age.

\section{Current situation of Children's English Teaching}

Children's English teaching is rising with the craze for English.Many parents in China attach great importance to the development of children's language ability,especially foreign language ability.Under the joint promotion of internal and external factors,the related children's English training institutions have sprung up everywhere in recent years,and many public colleges and universities have incorporated the training of children's English ability into the education and teaching system.But the current children's English Training Market Fish and dragon mixed,many institutions under the banner of cultivating children's language skills,but the actual teaching effect is not satisfactory.In the author's opinion,there are some problems in the teaching of Children's English in China:

\subsection{Faculty issues}

Teachers are the foundation of Education and teaching. Without good teachers,children's English education is impossible.At present,the biggest problem in children's English teaching lies in the teachers.College English teaching is very familiar to everyone.Although Children's English teaching is only two words away from college English teaching,there is a big difference between them. At present, various institutions, including teachers who teach children's English in schools, many of them simply understand English and even better understand teaching, but what are the characteristics of Children's English teaching Children's English teaching and adult English teaching in the end what are the differences,in the end a few people can speak clearly.Teachers of Children's English training institutions may have strong English professional skills,but how many people understand the characteristics and difficulties of teaching children? What is more worrying is that many people think that teaching children English will only be easier than teaching adults English. Not a few people hold this view,even some scholars engaged in educational research have ambiguous views in children's English education.

There is also the issue of children's learning environment.If you go to market to investigate,you will find that many of the current children's English training organizations are copying the learning environment of college students.The tables and chairs are complete,and the teachers are talking about the words.This kind of education teaching mode itself does not have how big problem,but if does not pay attention to the object that is taught,how big can the teaching effect to the child have?Many parents in the ideological also exist in a very big mistake.In some institutions, children's English teaching is a way of teaching and learning. When parents walk in and see the chaos,first of all,how do children in this environment learn?How is this managed?Such institutions were among the first to be discarded.It is the blindness of teachers and parents' ideological understanding that has caused the disorderly and chaotic chaos of children's English education. 


\subsection{Textbook Problems}

The problem of textbooks is also an issue that can not be ignored in children's English training.Speaking of teaching materials, this link seems not only in children's English teaching problems more prominent,primary school,junior middle school,high school,College,various learning stages in teaching materials can not meet the requirements of teaching problems.The problem is a stubborn one.Why can appear such problem,concern with our management mechanism above all.Our educational management mechanism is relatively conservative,and schools have very limited authority in the selection and adoption of teaching materials There are education authorities and other interest units.The selection of teaching materials has sometimes become the hardest hit area for corruption.At this point,foreign schools have a lot more control.Another,our textbook writing mechanism is not flexible enough,and some places do not fully commercial operation.In many cases,our textbooks need to be imported from abroad.At present,a lot of children's English teaching materials are introduced from the United States,the United Kingdom and other countries.There is a problem,these textbooks do not exist acclimatized,do not need to be localized transformation.This issue has not yet aroused enough attention,in any case,children's English training institutions have their own set of teaching materials. The problems with textbooks are more subtle.For example,if a teacher doesn't teach his students well,parents will basically point the finger at the teacher,believing that the teacher is incompetent and so on very few people focus on textbooks.Because of this,loopholes in textbooks have long plagued the education sector.The author has made a survey of several children's English teaching institutions in the market,and the teaching materials they use are basically different.As to why they choose these teaching materials.some people say that they are recommended by their friends,and some people say that they feel better than others Some people say it's cheap.The teaching material is the foundation of the education teaching,the teaching material is good or bad direct influence education teaching effect.Regrettably,there is currently no clear research report on children's English textbooks and no guidance.

\subsection{Evaluation System}

The test of children's language ability itself can not blame,but what is the scientific evaluation criteria and evaluation means is a big problem.In fact,the language is more embodied in the invisible.If you have to come up with a system for assessing language ability,it must be very complex and inter-linked.The evaluation system of Children's English teaching institutions is basically in a lower level,and many people even copy the university's English evaluation system.Such evaluation system can not consider children's language learning ability,also did not take into account the characteristics of learning children.

\section{Liberal education approach to teaching children's English.}

Children's English teaching should be guided by liberal education, which is determined by the characteristics of children's education itself,and is also the concrete reflection of the reform of education and teaching in our country.In Children's English teaching,we should focus on developing children's language perception,language ability and creative spirit,aiming at developing children's learning potential and stimulating children's enthusiasm in learning English.Liberal education teaching should focus on the following aspects: 


\subsection{Pay attention to the external environment, cultivate children's interest in learning}

In education and teaching,we should take into full account the children's age characteristics, children's psychological characteristics and growth laws,and they should be regarded as a special group. How to create a relaxed a comfortable learning environment is very important.Teachers should fully consider students' individual differences in teaching,try to teach in a relaxed and lively way, and must not create a serious and tense atmosphere.The serious image in traditional teaching should be avoided in children's teaching.Children's attention time is limited,teachers should make full use of this window period,and teach children English knowledge with a high degree of patience and kind language At the same time,children's understanding of English is weak,they are more to imitate,so we should not pay too much attention to children's English pronunciation accuracy,etc.In the long-term training,this problem will be well solved.

\subsection{Using a variety of teaching methods}

We should adopt various teaching methods in children's English teaching.For example,the teaching of knowledge can be completed in the game,can be a practical way to deepen children's understanding of a certain knowledge,and can use group discussion and other forms of active classroom atmosphere.I have been in contact with a children's English training institutions,I think that their teaching philosophy and teaching ideas are very close to the children's reality.They set up classes in different places,sometimes a supermarket,sometimes a racetrack,sometimes a restaurant,and so on.And they let kids play different roles in different places,sometimes a buyer,sometimes a boss.From the practical effect,children's enthusiasm and enthusiasm for learning is very high,the desire to learn knowledge is very strong,at the same time,this teaching method has also been received by parents and students alike

\subsection{Enhance Children's sense of participation}

One of the greatest characteristics of young children is that they are curious and willing to participate in practice.Therefore, we must create the condition as far as possible for them in the teaching,letting them participate in the education teaching. Many children may not have much desire for learning itself at the beginning just to participate in the mentality of play.But later he found that this thing is not only fun,but also can be recognized by those around him,so his interest will increase sharply From the inside out,there are dramatic changes.Promote children's sense of participation,let children in the interaction to achieve the ability and knowledge of the double promotion.

\section{Conclusion,}

Children's English teaching is a tedious and complex work,but it is an important part of the implementation of quality education strategy. For this point,we should have a clear understanding. Teachers in children's English teaching should pay attention to the development of children's interest in language learning, the development of children's innovative awareness and practical ability, which will play a good guiding role for children's future development.

\section{References}

[1] Zhao Shanna.The importance of environment creation for children's language development [J]. Education in Inner Mongolia, 2013(12)

[2] Miao Fangfang, Li Shanze.Nursery rhymes and language education [J].Chinese construction, 2013(11) 
[3] Guo Jidong. Interlanguage study of Children's English Learners [J]; An yang Normal University, 2005(06)

[4] Lei. Children's English teaching should focus on children's Lifelong Development [J]; Education Guide, 2003(12)

[5] Shao Chengyou.The application of situational approach in Primary School English Teaching [J].Chinese business circles.2010 (06)

[6] Zhou Jianhua.The orientation and development of Children's English Education [J].Basic Education.2003 (06) 